\title{
Preference for MBA Agribusiness Programme: A Conjoint Analysis
}

\author{
Bannor Richard Kwasi ${ }^{1}$, Surjeet Dhaka ${ }^{2}$ \\ ${ }^{1,2}$ Institute of Agribusiness Management, SK Rajasthan Agricultural University, India
}

\begin{abstract}
In an agricultural business based economy such as that of India, agribusiness opportunity becomes more important, so does higher education in agribusiness. In the light of these, a wakeup call to providing investments in education in the agriculture sector (production, transportation, processing etc) has surface the course of MBA Agribusiness Management. With growing demand for agribusiness, many agriculture universities are offering post graduate courses in agribusiness management which has led to increased competition of institutions in this sector. A conjoint analysis was used in the analysis of the preference of students for various agribusiness management schools based on assigned attributes (Fees per year, Placement for job, Location and recommendation). A conjoint analysis model was used to specify relationship between attributes and utility, which assumes that the overall utility derived from any combination of attributes, is the sum of the separate utilities of each level of an attribute. The study has shown that would be students and students of agribusiness students prefer institutions that assist students to get placement after completion of the course as the first and most important to consider for an agribusiness school, second is moderate fees (below 3 lakh per year), location in their home state and institution recommended by parents or an alumnus of that institution.
\end{abstract}

Key Words: Conjoint Analysis, Part- worth estimation, utility, attributes and levels

\section{Introduction}

Agriculture is fast changing into a business opportunity and with the increasing trends of transportation and exporting of food to the national and international markets after harvesting the crop by following technical methods of processing, packaging etc. Such changes in the global business scenario are phenomenal and will remain so in the coming decades, with the advent and the influence of new technologies. In an increasing agricultural business based economy, as agribusiness opportunity becomes more important, so does higher education (World Bank/OECD, 2006). In the light of these, a wakeup call to providing investments in education in the agriculture sector (production, transportation, processing etc) has surface the course of MBA Agribusiness Management (Singh 2013).

Agribusiness management is very important to developing countries like India to capitalize on the benefits of globalization and face new challenges to enhance the economy growth. Government, private and other organizations are looking forward for qualified agribusiness managers hence the central agricultural universities have taken up the responsibility of providing qualified human resources for this sector. With growing demand for agribusiness many agriculture universities are offering post graduate courses in agribusiness management ( Singh 2013), which has led to increased competition of institutions in this sector (Maringe and Gibbs, 2009)

Due to the intensification of globalization, competition and professionalism in the corporate world, agribusiness management education, no doubt, has become a central role in the success of students career especially those who enters into agribusiness oriented institutions and organizatons. Palacio et al. (2002) underscores that, for management institution to stay progressive and effective, students" expectations, academic preferences and quality perception about the educational environment should be kept by the higher authorities. The stakeholders such as students, parent and the organizations are interested to know more about the quality standards of an agribusiness management school and the opportunities it provides bearing in mind the fee structure (Gatfield, 1999)

The aims of MBA programs should be to help students gain a better understanding of the industrial and business world and its needs, thereby prepare them for managerial roles, enrich their skills and provide them with competencies relevant to their careers (Baruch and Lemming, 1996). Students, in particular of higher academic level seek more quality education and perfection of the system at the institute"s place as it satisfies their esteem and develops them with all the essential capabilities to be an effective educational personality (Malik et al., 2010)

One of such Agribusiness Management schools in Rajasthan State (Institute of Agribusiness Management) underscores its mission as to help agriculture and industrial sectors and develop core competence 
by bringing out professional managers, equipped with modern management theories, practices, appropriate behavioural values, skills with aptitude and sensitivity for agricultural and rural development(IABM,2014).

With the growing need of MBA Agribusiness by both the private sector and Government coupled with little or no documentary evidence of the preference of students for such programme, there is the need for a research in search area to undercover aforementioned questions and reasons empirically, hence the need for this research and also to add to knowledge.

The present study was designed to analyse the preference of students for MBA Agribusiness Programme with emphasis on a bundle of Attributes with a number of levels for each attribute. The attributes include; Fees per year, Placement, location and Recommendation.

\section{Study Area}

\section{Materials And Method Of Analysis}

The study was carried out in Swami Keshwanand Agriculture University in Rajasthan State of India. The university was chosen because of the existence of an Agribusiness school and the easiness to identify students who are in agribusiness programme and undergraduate students who are also in final year agriculture sciences and home science students who are interested in pursuing agribusiness management after their undergraduate courses.

\section{Identification of Attributes Analysis}

A survey using purposive sampling of 20 MBA Agribusiness management students in Institute of Agribusiness Management, 15 Alumnus of the Institute, 10 home science students and 15 final year agricultural students in Swami Keshwanand Agricultural University were used.

Students and alumnus were asked to choose based on some selected factors which influenced or will influence their choice of agribusiness management school. Giving these factors, students and alumnus were then made to rank these factors.

Respondents were made to rank cost of fees per year, placement, recommendation, scholarship, location and OGPA score and experience staff. A Garett ranking technique was used to get the most desirable attributes.

Based on the rank factors the following factors of Fees per year, location, placement and recommendation were settled on for preference analysis.

\section{Data Collection}

Multistage sampling design was employed for the study. The study area was conveniently and purposely selected (Convenience and probability sampling) because of the presence of an Institute of Agribusiness Management (IABM) which currently runs an MBA Agribusiness programme and also presence of other two colleges (college of Agriculture and College of Home Science). A simple random sampling was used to select 35 respondents in Institute of Agribusiness, 10 final year students in Home Science College and 15 final year students of college of Agriculture who are interested in opting for MBA Agribusiness programmes respectively. Both descriptive and inferential statistics were used to analyse the data collected.

\section{Conjoint Analysis}

Conjoint marketing research studies have been made in various specific business sectors such as grocery and candy products, life insurance, retailing (Toombs and Bailey, 1995), health club service retailers (Amirani and Baker, 1995), wine (Gil and Sanchez, 1997), financial service (Arias, 1996), and beef retailing (Hobbs, 1996). This current research applies conjoint analysis to measure utilities of various attributes among different type of students in Swami Keshwanand Rajasthan Agricultural University. Knowing which utility cues are most important to particular students, the agribusiness institutes and colleges can determine what should be promoted in order to lure these desired customers from their competitors.

Conjoint analysis was used to analyze students preference based on the attributes for an agribusiness management school. The reason being that, it enables trade-off between attributes to be established when multi attributes are taken together. With resource scarcity being an implicit fact in the real world, investment should be made to address those factors that matter most to the consumer. Conjoint analysis helps identify the factors that matter most to the different category of students that are included in the study by estimating the relative importance that each attach to a given factor in making a decision. Because the demand functions for the various categories of students differ, driven by utility based on limited factors per each student, it is expected that the relative importance that each student attach to the attributes will differ. However, despite these differences, conjoint analysis is able to also provide an overall relative importance that all the different category students attach to a given factor in making a choice of an agribusiness college.

Seven steps were taken in the conjoint analysis 
i. Establishing the attributes

ii. Assigning attribute levels

iii. Selecting the conjoint methodology

iv. Deciding which profile to present to the respondents

v. Establishing preference

vi. Choosing the presentation method

vii. Selecting a method for part-worth estimation

\section{Assigning Attribute Levels}

The attributes (fees per year, placement, location and recommendation) were used in the conjoint study. The levels chosen for each of the attributes in this study were assumed to be plausible, actionable and capable of being traded off as suggested by Pol and Ryan (1996) and communicable (Heir et al. 2006). Hair et al. (2006) suggest that to represent the respondent's judgment accurately, all attributes that create or detract the overall utility of the product must be included in the study. The levels of the attributes in the study were identified based on discussion with alumnus of agribusiness management schools, professors in agribusiness colleges and current students offering agribusiness management.

Table 1 below shows the attributes and their related levels as used in the study.

Table 1: Attributes and their related levels in the study
\begin{tabular}{|l|l|}
\hline \multicolumn{1}{|c|}{ ATTRIBUTE } & LEVEL \\
\hline Fees per year & Below 3lakh \\
\cline { 2 - 2 } & 3lakh-6lakh \\
\cline { 2 - 2 } & Above 6lakh \\
\hline \multirow{2}{*}{ Placement } & Yes \\
\cline { 2 - 2 } & Not \\
\hline Location & Familiar Climate \\
\hline & Cosmopolitan place \\
\hline \multirow{2}{*}{ Recommendation } & Home state \\
\hline & Parent \\
\cline { 2 - 2 } & Counsellor \\
\cline { 2 - 2 } & Alumnus \\
\hline
\end{tabular}

Source: Author's Computation, 2014

\section{Profiles Presentation}

Fractional factorial design was used to generate Orthogonal design, this design gives you the probable best combination of the all the levels mixed together. The fractional design was used to reduce the possible combinations to 9 with 4 holdouts combinations. This is because according to Kotri (2006), though the best practice is to allow the respondents to rate all possible combination, the respondent's ability to rate, when the combinations are many, reduces. The 9 profiles of combination are assumed to be orthogonal. Hair et al. (2006) suggest that, given a number of attributes and level, there are a minimum number of stimuli that can be employed and yet have a fair representation of all the factors under consideration. The minimum the study could have used is given as:

\section{Minimumunumberof stimuli $=$ Totalnumberoflevelsacrossallfactors - Numberoffactors +1}

Hence the minimum number of product combination that could have been used is as follows:

Total number of factors across all factors $\quad=3+2+3+3=11$

Number of attributes $=4$

Minimum number of products combination $=11-4+1$

$$
=8
$$

Hence the fractional factorial design that gave 9 combinations is within the requirement for a conjoint analysis, giving the number of factors and level.

\section{Establishing Consumer Preference in Conjoint Analysis}

Hair et al. (2006) indicate that there are two approaches to establishing preference in conjoint analysis. These approaches are the rank ordering approach and the ratings approach. This study used the rank ordering approach, where the respondents were made to rank the product combination from the most preferred to the least preferred. 


\section{Choice of Presentation Method}

To ensure realism and allow for the use of rankings, the study used the full profile method in obtaining respondents evaluations.

Table 2 shows example of two out of the 13 full product profiles used in the study.

Table 2: Two Representation of Full Product Profile Profile One

\begin{tabular}{|l|l|l|l|l|}
\hline Fees Per year & Placement & Location & Recommendation & Rank \\
\hline 3lakh-6lakh & No & Familiar Climate & Parents & \\
\hline
\end{tabular}

\begin{tabular}{|c|c|c|c|c|}
\hline \multicolumn{5}{|c|}{ Profile Two } \\
\hline Fees Per year & Placement & Location & Recommendation & Rank \\
\hline Above 6lakh & Yes & Familiar Climate & Counsellor & \\
\hline
\end{tabular}

Source: Author's Computation, 2014

\section{The Part-Worth Estimation Procedure (Conjoint Analysis)}

Analysis of the data is done with the conjoint procedure (available through command

Syntax in SPSS) and results in a utility score, called a part-worth, for each factor level. These utility scores, analogous to regression coefficients, provide a quantitative measure of the preference for each factor level, with larger values corresponding to greater preference. Part-worths are expressed in a common unit, allowing them to be added together to give the total utility, or overall preference, for any combination of factor levels. The partworths then constitute a model for predicting the preference of any product profile.

The study used the linear additive model to specify the relationship between the attributes and utility, which assumes that the overall utility derived from any combination of attributes, is the sum of the separate part worths (utilities) of each level of an attribute. Emery and Barron (1979) and Pol and Ryan (1996) suggest that other models such as the interactive model rarely result in a better fit than the linear additive model. The linear model is specified as:

$\mathrm{U}=\mathrm{A}_{0}+\mathrm{A}_{1}$ Fees per Year $+\mathrm{A}_{2}$ Placement $+\mathrm{A}_{3}$ Location $+\mathrm{A}_{4}$ Recommendation

Where $U$ denotes utility for a profile with a given level of each attribute, $A_{0}$ to $A_{4}$ denotes the coefficient of the model estimated. Fees per year, Placement, Location, and recommendation are the attributes included in the conjoint study. The relative importance $\mathrm{RI}_{\mathrm{i}}$ of an attribute " $\mathrm{i}$ ” is, then, given by:

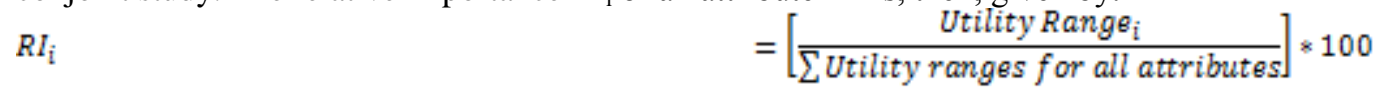

\section{Results And Discussion}

Table 3: Gender of Respondents

\begin{tabular}{|c|r|r|r|}
\hline Gender of Respondents & Frequency & Percent & Cumulative Percent \\
\hline Male & 33 & 55.0 & 55.0 \\
\hline Female & 27 & 45.0 & 100.0 \\
\hline Total & $\mathbf{6 0}$ & $\mathbf{1 0 0 . 0}$ & \\
\hline
\end{tabular}

Source: Author's Computation from field Data,2014

Table 2 shows the gender of the respondents. Males were highest with a percentage of $55 \%$ and Females having $45 \%$. This results shows that the number of students undertaking the course and students willing to take part in the course are predominantly males. Measures should also be undertaken to encourage females to take part in MBA Agribusiness courses as they also form a sizeable part of the population of India and their involvement in the areas of agribusiness will contribute to the socio-economic development of the country and females.

Table 4: Family Income of Respondents

\begin{tabular}{|c|c|c|c|c|}
\hline $\begin{array}{l}\text { Family Monthly } \\
\text { Income( Rupees) }\end{array}$ & Frequency & Percent & Valid Percent & Cumulative Percent \\
\hline below 10000 & 4 & 6.7 & 6.7 & 6.7 \\
\hline $10000-30000$ & 17 & 28.3 & 28.3 & 35.0 \\
\hline $30001-60000$ & 35 & 58.3 & 58.3 & 93.3 \\
\hline $60001-90000$ & 4 & 6.7 & 6.7 & 100.0 \\
\hline Total & $\mathbf{6 0}$ & $\mathbf{1 0 0 . 0}$ & $\mathbf{1 0 0 . 0}$ & \\
\hline
\end{tabular}

Source: Author's Computation from field Data, 2014 
Table 3 shows that majority of the respondents interviewed families income ranges between 30001 60000 a month representing $58.3 \%$ of the respondents. Only 6.7 percent with a number of 4 students' families' incomes is less than 1000 a month. Again only 4 students also representing $6.7 \%$ of the respondents monthly family income is between 60001-90000. This family income will have great effect on the fee structure that a respondent will prefer for an MBA programme since their utility level will have to be within the family income. In addition, the results shows that most students whose families income is less than 10000 Rupees a month a less likely to opt for MBA Agribusiness Programme however most of families with such incomes are the ones that involve in agriculture and agriculture related businesses. Hence students from such income group should be encouraged to participate in such programmes through scholarships so as to encourage them to contribute immensely towards the economic development of their families and the country as a whole.

Table 5: Age of Respondents

\begin{tabular}{|c|c|c|c|}
\hline Age of Respondents & Frequency & Percent & Cumulative Percent \\
\hline Below 20 & 1 & 1.7 & 1.7 \\
\hline $20-25$ & 54 & 90.0 & 91.7 \\
\hline $26-30$ & 5 & 8.3 & 100.0 \\
\hline Total & & & \\
\hline
\end{tabular}

Source: Author's Computation from field Data, 2014

The table shows that the group of the respondents ranges between below 20 to 30years. Which indicates all the respondents are in their youthful stage which when educated well especially in agribusiness management will have significant effect in the agriculture sector. This also gives credence to the fact that Indian population has a huge a number of youth. The age group with the highest frequency is 20-25 with percentage of $90 \%$ followed by $26-30$ years with percentage of $8.3 \%$ of respondents. About $90 \%$ of respondents being in the age group of 20-25 can easily affect the recommendation for agribusiness school by parents. This is because at this age most decisions in families are made by parents especially in relation to the school one attends.

Table 6: Estimated Utilities of the Attributes

\begin{tabular}{|c|c|c|c|c|c|}
\hline \multirow[t]{2}{*}{ ATTTRIBUTES } & \multirow[t]{2}{*}{ LEVELS } & \multicolumn{2}{|c|}{ UTILITY ESTIAMATES } & \multirow{2}{*}{$\begin{array}{l}\text { STANDARD } \\
\text { ERROR FOR MBA } \\
\text { RESPONDENTS } \\
\text { ONLY }\end{array}$} & \multirow{2}{*}{$\begin{array}{l}\text { STANDARD } \\
\text { ERROR } \\
\text { JOINT FOR } \\
\text { RESPONDENTS }\end{array}$} \\
\hline & & $\begin{array}{l}\text { MBA } \\
\text { students } \\
\text { respondents } \\
\text { only }\end{array}$ & $\begin{array}{l}\text { Joint of All } \\
\text { respondents }\end{array}$ & & \\
\hline \multirow[t]{3}{*}{ Fees Per Year } & Below 3lakh & 1.058 & 0.661 & 0.233 & 0.303 \\
\hline & 3-6lakh & 0.085 & 0.224 & 0.233 & 0.303 \\
\hline & Above 6lakh & -1.143 & -0.885 & 0.233 & 0.303 \\
\hline \multirow[t]{2}{*}{ Placement } & Yes & 1.575 & 1.074 & 0.175 & 0.227 \\
\hline & No & -1.575 & -1.074 & 0.175 & 0.227 \\
\hline \multirow[t]{3}{*}{ Location } & Home state & 0.865 & 0.525 & 0.233 & 0.303 \\
\hline & $\begin{array}{l}\text { Familiar } \\
\text { Climate }\end{array}$ & -0.547 & -0.125 & 0.233 & 0.303 \\
\hline & $\begin{array}{l}\text { Cosmopolitan } \\
\text { city }\end{array}$ & -0.404 & -0.404 & 0.233 & 0.303 \\
\hline \multirow[t]{3}{*}{ Recommendation } & Parents & 0.102 & 0.246 & 0.233 & 0.303 \\
\hline & Alumnus & 0.418 & 0.104 & 0.233 & 0.303 \\
\hline & Counesllor & 0.520 & -0.350 & 0.233 & 0.303 \\
\hline Constant & & 4.461 & 4.642 & 1.75 & 0.227 \\
\hline
\end{tabular}

Source: Author's Computation from conjoint Analysis using SPSS $2 \mathrm{O}$

Table 6 shows the utility part worth scores by respondents and their standard errors. The parth worth analysis gives higher utility for higher preference. From the Table, on the attribute of Fees per Year, an amount below 3lakh and 3lakh-6 lakh gave a positive utility value. Below 3 lakh had the biggest preference or utility value of 1.058 and 0.661 for MBA agribusiness respondents and Joint respondents ( MBA Agribusiness) students, final year students in college of agriculture and Home Science College) respectively. The figure shows that when the fees structure per year decreases the preference level of respondent's increases and also decreases when the fee per year increases. The negative utility value for above 6lakh level of fees per year shows that, as the fees for MBA programme increases, the preference for respondents decreases which can be attributed to the family monthly income.

Again for the Placement column, the analysis shows that, respondents also prefer MBA institutions that will give placement. This is true for MBA respondents and all the respondents put together. This according to many interviewed was because the idea of taken an MBA programme they believe, will make them more 
marketable as agricultural graduates in terms of employability hence will prefer an institution that gives or assist its graduates to get employment after completion of the course. The need for placement by students who are enrolled in MBA programme and prospective MBA students can be attributed also to the unemployment situation in the country. Unemployment, according to Wikipedia is $8.5 \%$ in the country as at 2012. National Sample Survey Organisation (NSSO) under the Government India $61^{\text {ST }}$ Round report of India, suggested that, the possibility of being unemployed rises with increasing education and skills. NSSO surveys conducted over the years show that the unemployment rate among those educated above the secondary level was higher, in both rural and urban areas, than those with lesser educational attainments. The NSSO 61st Round report, Employment and Unemployment Situation in India 2004-05, attributes this partly to the fact that "the job seekers become gradually more and more choosers as their educational level increases partly to the high population of the country (Press Information Bureau,2014). Commenting on such scenario, Serneels (2007) also found that, in Ethiopia unemployment is concentrated among relatively well-educated first time job seekers who come from the middle classes of which would be MBA students and current MBA students wouldn't be different from after completion of their courses.

The negative value of -1.575 and -1.074 for an agribusiness institute that does not give placement for job shows students do not prefer such schools.

On the issue of Location, most of the respondents prefer to be in home state. This gives a positive utility value of 0.865 and 0.525 for both respondents. This according most of the students interviewed is the pride they give to schools in home state and the closeness to family. The analysis further proved that, MBA respondents prefer to enroll in an MBA programme recommended by and alumnus of that college but the joint respondent analysis proved the students will prefer recommendation by parents this might be partly due to the age group of respondents and dependence on parents for such decisions. In addition, the respondents having a higher utility level for MBA institutions that has been and will be recommended by parents is line with Asia Society 2014 report on Indian Society and Ways of Living. According to the society, Indian household lines of hierarchy and authority are clearly drawn, and ideals of conduct help maintain family harmony. All family members are socialized to accept the authority of those above them in the hierarchy. The eldest male acts as family head and the youngest like most prospective and current MBA Students interviewed have the least authority.

In calculating the Utility levels using the utility estimation per each profile as shown in figure 2 below the best first two utility profiles that students prefer was the following:

First Best Profile

\begin{tabular}{|l|l|l|l|l|}
\hline Fees Per year & Placement & Location & Recommendation & Rank \\
\hline Below 3lakh & Yes & Home state & Parents & 1st \\
\hline
\end{tabular}
\begin{tabular}{|l|l|l|l|l|}
\hline Fees Per year & Slacement & Location & Recommendation & Rank \\
\hline Below 3lakh & Yes & Familiar Climate & Alumnus & 2nd \\
\hline
\end{tabular}

The above two profiles gave higher total utility values of 8.06 and 6.96 respectively. The least utility profile was (3-6lakh,no placement, familiar climate and parents recommendation) with utility of 2.53.

Table 7: Relative Importance of Attributes in Conjoint Analysis

\begin{tabular}{|l|l|l|}
\hline Attribute & $\begin{array}{l}\text { Importance values for MBA Respondents } \\
\text { only }\end{array}$ & $\begin{array}{l}\text { Importance Values for } \\
\text { Joint Respondents }\end{array}$ \\
\hline Fees Per Year & 28.588 & 29.634 \\
\hline Placement & 40.888 & 41.152 \\
\hline Location & 18.337 & 17.801 \\
\hline Recommendation & 12.187 & 11.414 \\
\hline
\end{tabular}

Source: Author's Computation from the conjoint Analysis

The importance that MBA Agribusiness students gave to the various attributes in relation to the joint respondent's analysis clearly shows little difference. However the trend is same for the two. In all, the highest importance for all the attributes is placement (assistance to get job after completion of the program). This is no surprise since India has huge youthful population that are looking for job hence most students will prefer institutes or colleges that could assist in that direction. Placement commands importance of $41.152 \%$ for the whole attributes with Fees per year having 29.634\% importance with location also having the third importance with $17.0801 \%$. Recommendation though is fourth according to the other of importance but also have a significant importance of $11.414 \%$. 


\section{Conclusions}

\section{Conclusion And Recommendation}

The result of the conjoint analysis revealed that, students prefer MBA Agribusiness colleges with fees per year less than 3lakh and also utility levels of students go down as fees per year increases. In addition, the students on the attribute of location will prefer MBA colleges in home state and also takes into consideration of parents and alumnus in selecting and MBA Agribusiness College. The most important attribute in selecting an MBA Agribusiness College is the one that places students in jobs after graduation and students preference for colleges that do otherwise decreases sharply.

\section{Recommendations}

- MBA Agribusiness colleges should be considerate and mindful of the amount of fees they charge per year as it can affect the number of students that will be willing to be admitted into such schools.

- MBA Agribusiness colleges and institutes should do much promotion of the schools in their home states as most students prefer home state colleges

- Alumnus and Parents should be use as channel for marketing colleges. It is important that before an MBA students graduates, he or she must be thought to know his school very much so as to promote the college.

- Further research should be done purposively into high fee paying institutes preference and what attributes really affect the preference for such institutes

- MBA Agribusiness colleges should be able trained more entrepreneurs to reduce the unemployment rate in the country than seemingly doing placement agency work for students.

\section{References}

[1]. Amirani, S. and Baker, J. (1995), Quality cues and retail target market strategy: a conjoint- based application", International Journal of Retail \& Distribution Management, Vol. 23 No. 5, pp. 22-31

[2]. Arias, J.T.G. (1996), Conjoint-based preferential segmentation in the design of a new financial Service", International Journal of Bank Marketing, Vol. 14 No. 3, pp. 30-2.

[3]. Asia Society (2014), Indian Society and Ways of Living, Organization of Social Life in India, "family Authority and Harmony" Retrieved from http://asiasociety.org/countries/traditions/indian-society-and-ways-living on 15/05/2014

[4]. Baruch, Y. and Lemming, A. (1996), "Programming the MBA - the quest for curriculum",

[5]. Journal of Management Development, Vol. 15 (7), pp. 27-36.

[6]. Gatfield, T.; Barker, M. and Graham, P. (1999), "Measuring Student Quality Variables and the Implications for Management Practices in Higher Education Institutions: an Australian and international student perspective, Journal of Higher Education Policy and Management, Vol. 21 (2) pp. 239-252.

[7]. Gil, J.M. and Sanchez, M. (1997), Consumer preferences for wine attributes: a conjoint Approach", British Food Journal, Vol. 99 No. 1, pp. 3-11.

[8]. Hair, J. F., Anderson, R. E., Tatham, L. R., \& Black, W. C. (2006). Multivariate Data Analysis (5 ed.). New Jersey: Prentice-Hall PTR.

[9]. Hobbs, J.E. (1996), A transaction cost analysis of quality, traceability and animal welfare issues in UK beef retailing", British Food Journal, Vol. 98 No. 6, pp. 16-26

[10]. IABM. (2014) Retreived from :http://www.iabmbikaner.org/webpages/MissionAndObjectives.aspx on 13/05/2014

[11]. Kotri, A. (2006). Analyzing Customer Value Using Conjoint Analysis: The Example of a Packaging Company. Tartu: Tartu University Press.

[12]. Maringe F. and Gibbs P. (2009), Marketing Higher Education: Theory and Practices, Open University Press, McGraw-Hill Education, England Malik, MuhammedEhsan; Danish, RizwanQaiser and Usam, Ali (2010), "The Impact of Service Quality on Students $^{\text {ee }}$ Satisfaction in Higher Education Institutes of Punjab, Journal of Managemen Research, Vol. 2 (2).

[13]. Palacio, A. B.; Meneses, G. D. and Perez, P. J. P. (2002), "The configuration of the university image and its relationship with the satisfaction of students", Journal of Educational Administration, Vol. 40 (5), pp. 486-505.

[14]. Pol, M., \& Ryan, M. (1996). Using conjoint analysis to establish consumer preferences for fruit and vegetables. British Food Journal, 98, 5-12.

[15]. Press Information Bureau (2014), Ministry of Statistics and Programme Implementation, "Key Indicators of Employment and Unemployment in India 2009-2010", Retrieved from http://pib.nic.in/newsite/erelease.aspx?relid=72839 on 15/05/2014

[16]. Sahadeva Singh. (2013). Retreived from http://aiasa.in/aiasa7/article/career-opportunities-agri business- management) on $13 / 05 / 2014$

[17]. Serneels, P.M. (2007): 'The nature of unemployment among young men in urban Ethiopia', Review of Development Economics" 11(1), 170-186.

[18]. Toombs, K., and Bailey, G. (1995), How to redesign your organization to match customerneeds", Managing Service Quality, Vol. 5 No. 3, pp. 52-6.

[19]. World Bank, OECD and Nuffic International workshop (2006), Cross-border higher education for capacity development, The Hague, Netherlands, available at http://www.oecd.org/edu/ceri/theworldbankoecdandnufficinternationalworkshoponcrossborderhighereducationforcapacitydevelopmentthehague14-15september2006.htm

[20]. Wikipedia (2014). Retrieved from http://en.wikipedia.org/wiki/List of countries by unemployment rate\#cite note-CIA-1 On $28 / 5 / 2014$ 